ఠ

\title{
Incidence density of serious infection, opportunistic infection, and tuberculosis associated with biologic treatment in patients with rheumatoid arthritis - a systematic evaluation of the literature
}

\author{
This article was published in the following Dove Press journal: \\ Open Access Rheumatology: Research and Reviews \\ 19 March 2013 \\ Number of times this article has been viewed
}

\section{Trung N Tran' \\ Herve Caspard' \\ Fabio Magrini}

'Clinical Development, Medlmmune, Gaithersburg, MD, USA; ${ }^{2}$ Eli Lilly, San Diego, CA, USA
Correspondence: Trung N Tran Clinical Development, Medlmmune, One Medlmmune Way, Gaithersburg, MD 20878, USA

$\mathrm{Tel}+\mathrm{I} 3013985406$

Fax +I 30I 3989982

Email trantr@medimmune.com

\begin{abstract}
Summary data on the incidence density (ie, incidence per person-year [PY]) of serious infection, opportunistic infection, and tuberculosis associated with each of the nine biologic therapies currently indicated in rheumatoid arthritis patients are not available. To summarize these data, a systematic review was conducted with searches on PubMed and Embase of literature ranging from January 1998 to November 2011. Incidence density was extracted and reported using the definitions from the respective publications. If the incidence density was not reported, estimation was made using available information. A total of 72 published studies met the inclusion criteria and were reviewed, including 44 clinical trials, open-label extension studies, or meta-analyses, and 28 observational studies. Additional calculation of the incidence density was performed in 12 studies for serious infection and in 13 studies for opportunistic infection or tuberculosis. The incidence of serious infection was consistent across studies and biologic therapies, ranging from 0 to 11/100 PY but mainly clustered from 2 to 6/100 PY. Fewer incidence data were available for opportunistic infection and tuberculosis. The incidence of opportunistic infection and tuberculosis ranged widely, from 0.01 to 3.0/100 PY and 0.01 to 2.6/100 PY, respectively. The data on serious infection may be used to evaluate the public health risk and benefit of biologic treatment. They may also serve as a point of reference for future studies. The limited data on opportunistic infection and the lack of a consistent definition of opportunistic infection invite caution for a benchmark rate for opportunistic infection as a composite category.
\end{abstract}

Keywords: DMARD, biologic, review, safety, infection, adverse event

\section{Introduction}

Rheumatoid arthritis (RA) is a form of inflammatory arthritis characterized by joint and systemic inflammation that can lead to significant disability, morbidity, and increased mortality. Treatment options for RA include nonbiologic (traditional) disease-modifying antirheumatic drugs (DMARDs), often used as a single agent or in combination, and newer biologic DMARDs, which are most commonly used in combination with methotrexate (MTX). ${ }^{1}$ As of November 2011, there were nine biologic DMARDs approved in the United States for the treatment of RA, targeting different B- and T-cell pathways, including five tumor necrosis factor (TNF) inhibitors, an antiinterleukin (IL)-1, an anti-CTLA4, an anti-CD20, and an anti-IL-6. The treatment objective is to regulate the activation of the immune system and reduce inflammation. 
However, both traditional and biologic DMARDs can cause some degree of immunosuppression, potentially exposing patients to a higher risk of contracting infections. Therefore, among others, infections can be a significant side effect of RA treatment. ${ }^{2,3}$

Many observational studies, meta-analyses, and literature reviews have examined whether biologic therapies increase the risk of serious infection (SI), although the findings were inconsistent. ${ }^{2,4-6}$ Given the rarity of opportunistic infections (OIs), few summary data were available for this outcome. Tuberculosis (TB), sometimes considered an OI, may be associated with biologic therapies. ${ }^{7,8}$ Although the majority of studies focused on the association of biologic therapies and the risk of SI, summary data on the absolute incidence of SI, OI, and TB associated with exposure to biologic DMARDs in RA patients are not available. Assessing the absolute incidence of infections associated with biologic DMARDs is important and necessary to guide treatment decisions and facilitate the assessment of each drug's public health risk and benefit. Such data can also provide a benchmark for future studies of existing or new therapies. To achieve this, the analysis that follows focuses on the incidence density (ie, incidence rate per person-time) of SI, OI, and TB in RA patients treated with biologic DMARDs and MTX.

\section{Methods}

A systematic review of the literature following the Preferred Reporting Items for Systematic Reviews and Meta-Analysis (PRISMA) guidelines was conducted. Searches on PubMed and Embase included the following keywords: rheumatoid arthritis, [incidence or rate or frequency], and [safety or infection or tuberculosis], in combination with each of the following terms: etanercept, infliximab, adalimumab, certolizumab, golimumab, rituximab, abatacept, anakinra, tocilizumab, and methotrexate. A manual search of articles cited in the meta-analyses or review papers was also conducted. For most molecules, only papers published from 2001 and onward were considered. For MTX and older molecules like infliximab or anakinra, papers published from 1998 and onward were included. The search was conducted by the lead author and validated by a librarian. They discussed the search results and came to a consensus on inclusion. From an initial review of the abstracts, the list of articles was then narrowed to meta-analyses, randomized clinical trials (RCTs) or their open-label extensions (OLEs), and observational safety studies. The following criteria were used to exclude articles: lack of an abstract, studies with less than 100 subjects in the treatment group, no English version available, review articles, and case reports. If for a particular molecule there were already five or more clinical trials that reported the incidence density, we excluded those trials that reported only the cumulative incidence (ie, proportions of infected patients), but did not report the incidence density. If there were several articles from the same study, each with varying follow-up, only the most recent article (ie, the longest follow-up) was used, unless the earlier article presented the incidence density and the later article(s) did not. Details of the search and its results are presented in Figure 1.

The overall incidence density of SI, OI, and TB was extracted and reported using the definitions from the respective publications. If the overall incidence density was not available, the range of incidence by doses was reported instead. The definition of SI and OI was noted for each study if available. In clinical trials that did not report the incidence density, the incidence density was estimated as the ratio of the number of cases over the total person-time of follow-up. If the exact total person-time was not provided, it was calculated as the product of the number of subjects at the beginning of the follow-up and the average duration of follow-up. In some cases in which only the patient-disposition information was available, an assumption had to be made that withdrawals from the trial were evenly distributed during the follow-up to be able to estimate the total person-time. The following formula was used:

$$
\mathrm{PT}=\mathrm{T} \times\left(\mathrm{N}_{1}+\mathrm{N}_{2}\right) / 2
$$

where PT was the person-time, $\mathrm{N}_{1}$ was the number of subjects at the beginning of the follow-up, $\mathrm{N}_{2}$ was the number of subjects at the end of the follow-up, and $\mathrm{T}$ was the duration of the follow-up period. The results were grouped into two main categories, namely evidence from clinical trials and from observational studies.

\section{Results}

In total, 72 literature articles met the inclusion criteria and were reviewed. Among them, 44 were RCTs, OLEs, or meta-analyses of clinical trials, and 28 were observational studies. In RCT or OLE studies, SI was often defined as an infection that required hospitalization or intravenous (IV) antibiotics or that met the regulatory definition of a serious adverse event (SAE, ie, events that are fatal, life-threatening, requiring or prolonging hospitalization, resulting in persistent or significant disability, or other events that are medically significant) (Table 1). In observational studies, the majority 


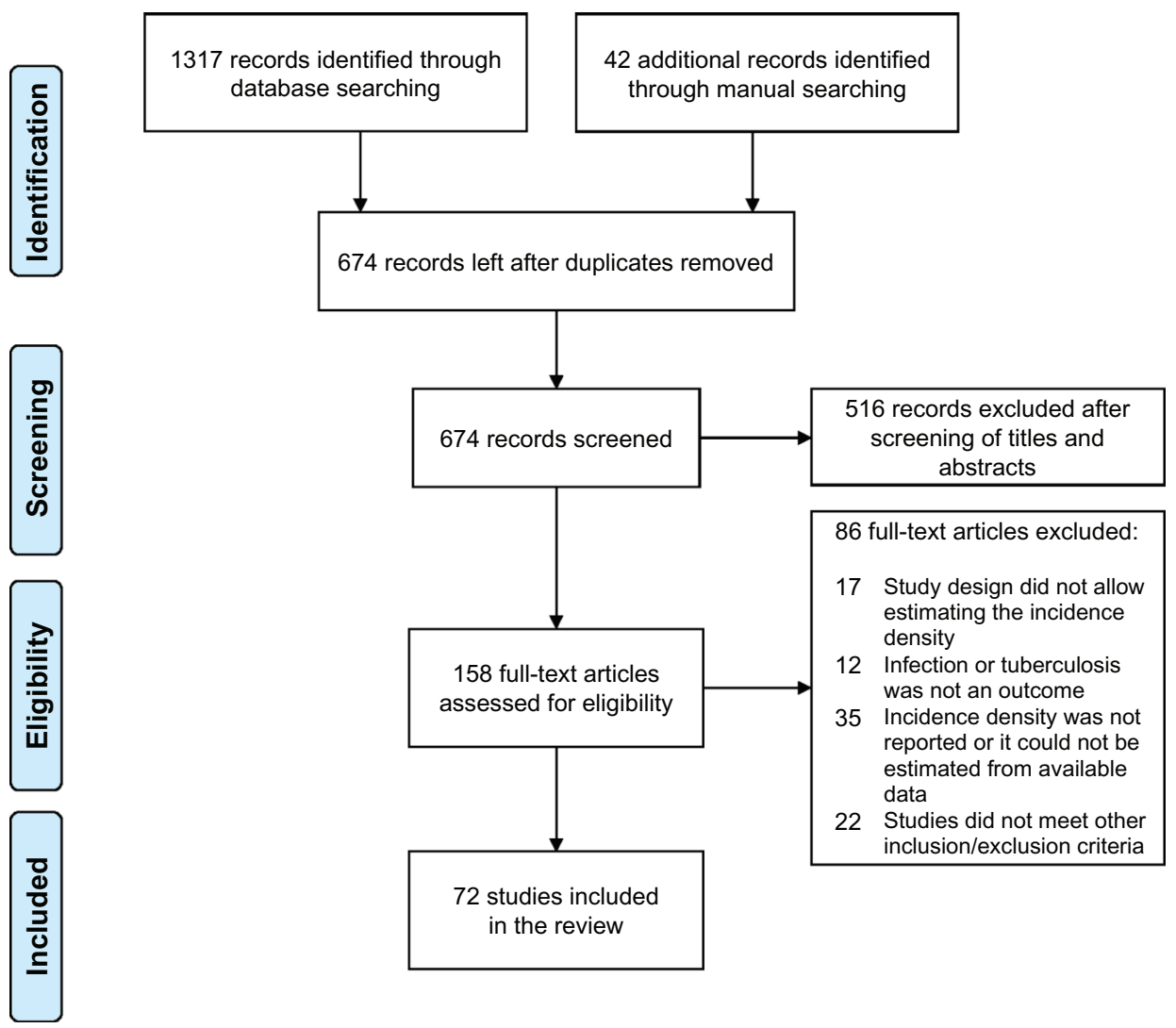

Figure I Flow diagram of the systematic search.

of studies defined SIs as those requiring hospitalization. Some observational studies defined an SI as one requiring hospitalization, IV antibiotics, having a fatal outcome, or used a physician diagnosis of SI (Table 2). The definition of OI was often not presented in published studies. In some clinical trials, OIs were defined using the US Centers for Disease Control and Prevention's criteria. ${ }^{9}$

In most RCTs with biologics in RA, MTX is used as a stable background medication in all treatment groups including the controls. The majority of RCTs did not report the incidence of infections in the control group. Available data for MTX mostly came from the control group in clinical trials or from observational studies with biologic DMARDs. Among the 72 articles reviewed, additional analyses were conducted to estimate the incidence density of SI in $12^{10-21}$ articles and of OI or TB in $13^{10,12-16,22-28}$ articles, of which all were reporting results from clinical trials or their extensions (estimated figures are noted in Table 1). The calculated incidence density was generally consistent with the range of incidence density from studies that provided the exact incidence. Among the molecules, infliximab and golimumab were the two biologics that required the majority of calculations for the incidence density.

\section{Serious infections}

The incidence of SI across biologic DMARDs ranged from 0 to 11.1 per 100 person-years (PY). Excluding one trial that reported no SIs, ${ }^{29}$ all studies were in the range of $\sim 2-11$ per $100 \mathrm{PY}$, and the majority of studies reported a narrower range of $\sim 2-6 / 100$ PY (Tables 1 and 2). Results from observational studies were consistent with those from clinical trials. Regarding TNF inhibitors or biologic DMARDs as a group, observational studies produced results that were similar to the data for individual molecules. Among observational study participants, the ranges of incidence of SI associated with TNF inhibitors and biologic DMARDs (including TNF inhibitors and non-TNF inhibitors) were 2.2-10.4/100 PY and 4.6-7.0/100 PY, respectively (Table 2). The former was also consistent with results of a meta-analysis of 18 RCTs in more than 8800 RA patients that reported the incidence of SI associated with TNF inhibitors to be 3.6/100 PY. ${ }^{4}$ The corresponding incidence associated with MTX ranged from 1.0 to $8.8 / 100$ PY (Table 1), which was not different from the range observed for nonbiologic DMARDs as a group (1.3-9.6/100 PY). (Table 2)

Among RCTs or OLEs and excluding meta-analyses, there was no important difference in the distribution of 


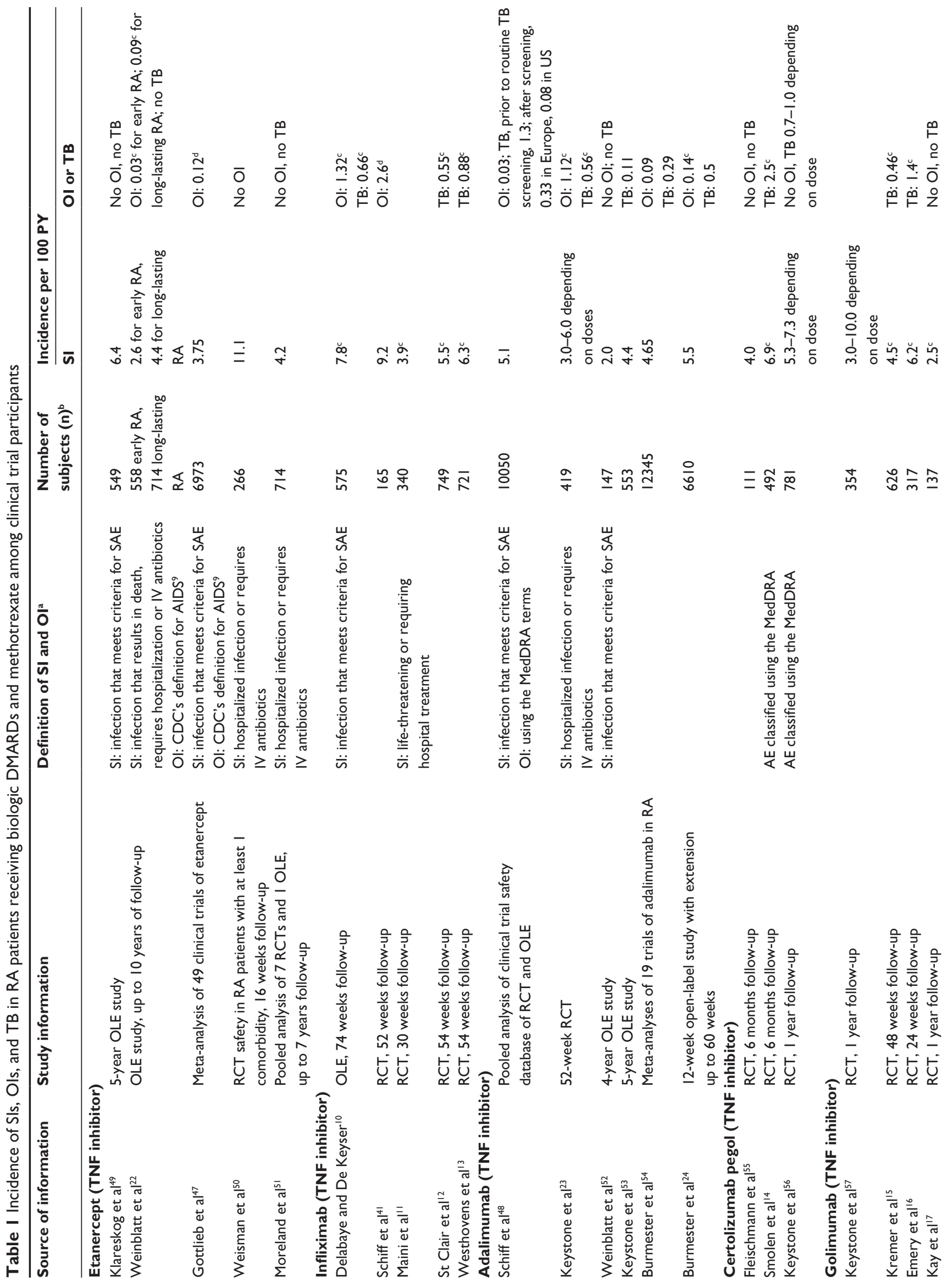




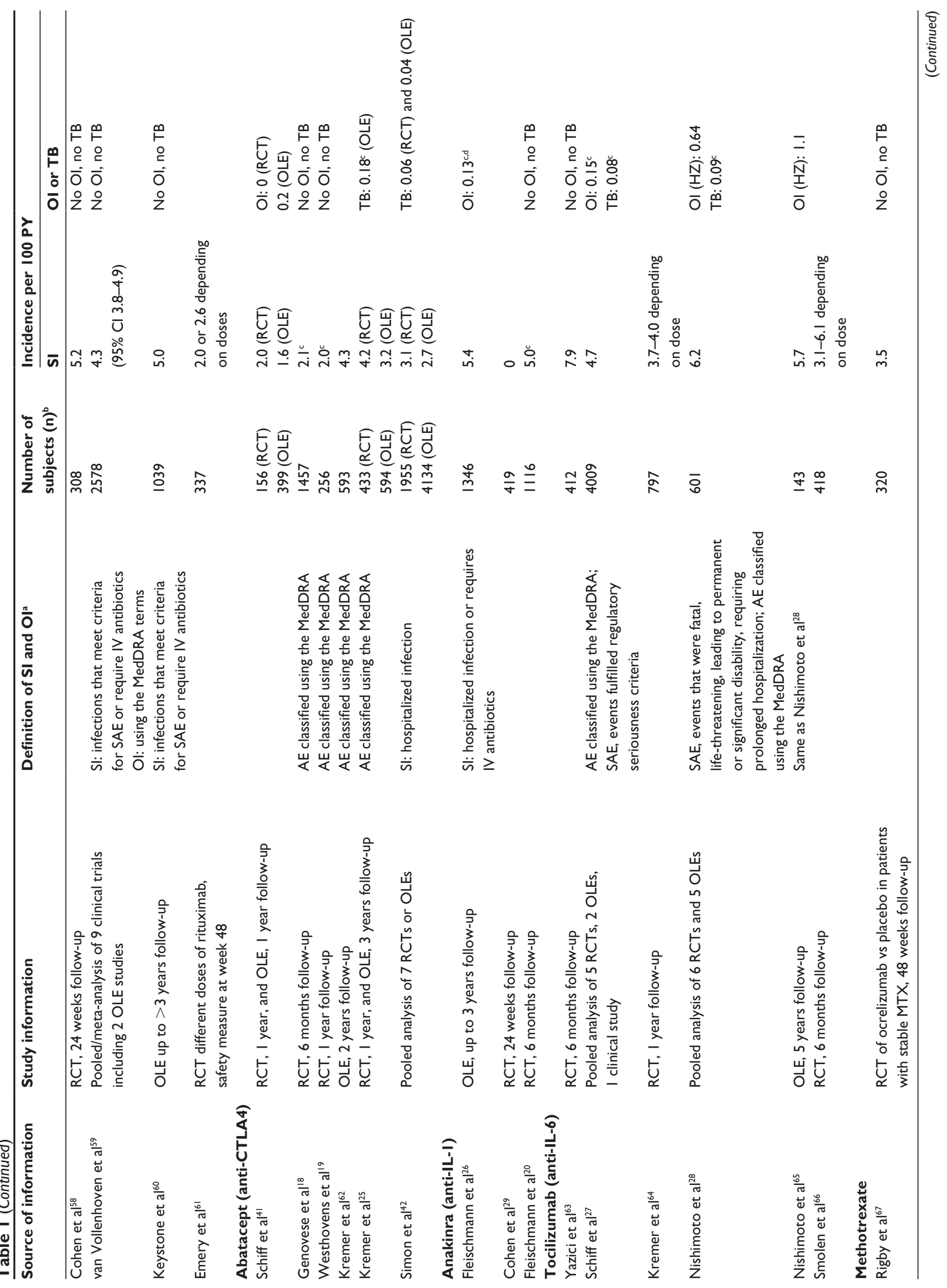




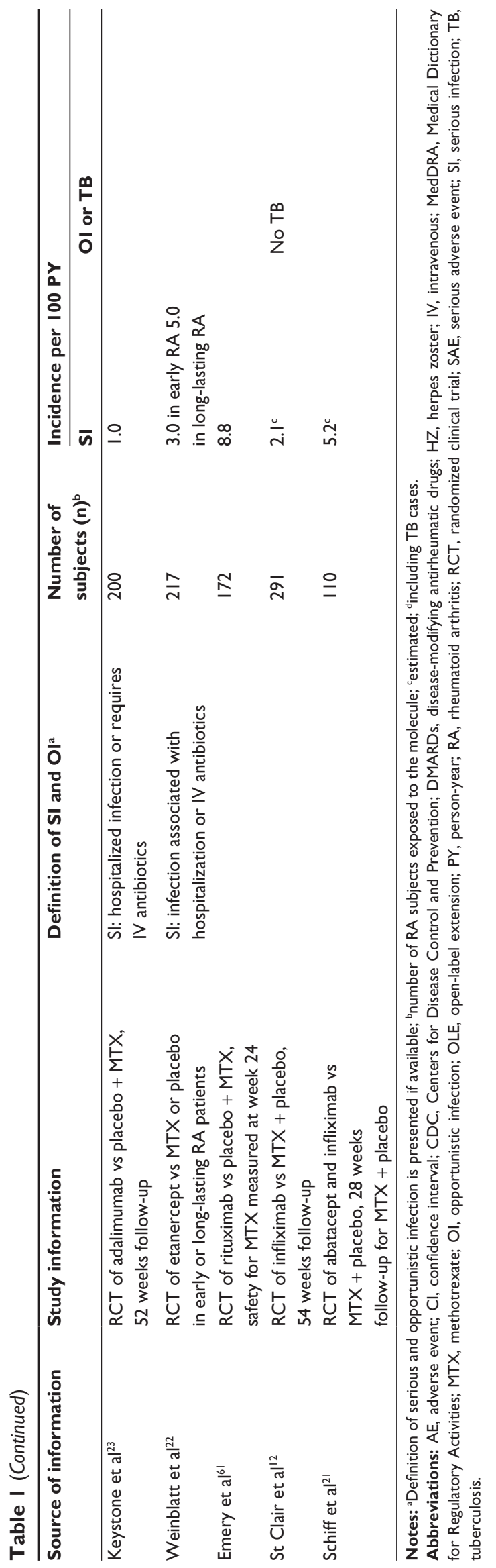

incidence density of SI by durations of follow-up, ie, 26 weeks or less, from more than 26 weeks to 54 weeks, and more than 54 weeks (Figure 2).

\section{Opportunistic infections and tuberculosis} Incidence data for OI and TB were reported far less frequently than for SI. Among trials that reported OI and TB, the incidence of OI and TB ranged from 0.03 to $2.6 / 100$ $\mathrm{PY}$ and 0.04 to $2.5 / 100 \mathrm{PY}$, respectively (Table 1 ). Two observational studies reported an incidence of OI (including TB) of 2.5-3.0/100 PY ${ }^{30}$ and of non-TB OI of $0.15 / 100 \mathrm{PY}^{31}$ among those receiving TNF inhibitors. Several observational studies reported an incidence of TB of $0.01-0.10 / 100 \mathrm{PY},{ }^{32}$ 0.05-0.38/100 PY, ${ }^{33-35}$ and 0.01-2.6/100 $\mathrm{PY}^{36-38}$ during the period before, after, and both before and after 2001, respectively (data not shown), when TB was first recognized as a potential adverse event in patients receiving biologic therapy. ${ }^{39}$ Among the studies that reported an incidence of TB, one was conducted in South Korea, where TB may be endemic; ${ }^{36}$ all other studies were from the US or Western European countries.

\section{Discussion}

Despite a large number of studies on the safety of biologic treatment in RA patients, to our knowledge few summaries of the absolute incidence of SI, OI, and TB associated with biologic DMARD treatment in RA patients were available. The majority of literature reviews and meta-analyses focused on whether biologic DMARDs increased the risk of SI (ie, focused on the relative risk), but did not discuss the absolute incidence of infections. An earlier review by Furst ${ }^{40}$ looked at the absolute incidence of infections associated with six biologics in RA patients that did not include newer biologics such as certolizumab, tocilizumab, and golimumab. Furst's review ${ }^{40}$ presented cumulative incidence estimates or incidence-density estimates. To our knowledge, our analysis is the first that discusses incidence-density estimates of SI, OI, and TB associated with each of the nine biologics indicated in RA patients as of November 2011. The incidence of SI was relatively consistent across biologic DMARDs and between clinical trials and observational studies, ranging from $\sim 0$ to 11/100 PY. The majority of studies clustered a narrower range, approximately 2.0-6.0/100 PY. There was only one study, a 24-week clinical trial of anakinra, where no cases of SI were reported. ${ }^{29}$ The findings of this study are inconsistent with results from the other two studies of anakinra reporting an incidence of 5.0-5.4/100 PY ${ }^{20,26}$ (Table 1). Even though this analysis is not meant to discuss the difference in 
Table 2 Incidence of serious infections in RA patients receiving biologic and nonbiologic DMARDs among observational study participants

\begin{tabular}{|c|c|c|c|c|}
\hline Studies & Study information & Definition of SI & Drugs & Incidence per I00 PYa \\
\hline $\begin{array}{l}\text { Lacaille } \\
\text { et al }{ }^{68}\end{array}$ & $\begin{array}{l}\text { Retrospective cohort study } \\
\text { using administrative data, } \\
\text { Canada, } n=27,710,1996-2003\end{array}$ & $\begin{array}{l}\text { Requiring } \\
\text { hospitalization }\end{array}$ & $\begin{array}{l}\text { MTX } \\
\text { Immunosuppressive DMARDs } \\
\text { Nonimmunosuppressive } \\
\text { DMARDs }\end{array}$ & $\begin{array}{l}4.5 \\
5.1 \\
4.6\end{array}$ \\
\hline $\begin{array}{l}\text { Lane } \\
\text { et } \mathrm{a}^{43}\end{array}$ & $\begin{array}{l}\text { Retrospective cohort study, } \\
\text { VA system (US), } n=20,8 \mid 4 \text {, } \\
\text { I998-2005 }\end{array}$ & $\begin{array}{l}\text { Requiring } \\
\text { hospitalization }\end{array}$ & $\begin{array}{l}\text { Etanercept, infliximab, } \\
\text { adalimumab } \\
\text { MTX, leflunomide, } \\
\text { azathioprine, cyclophosphamide, } \\
\text { cyclosporine, anakinra } \\
\text { Hydroxychloroquine, } \\
\text { sulfasalazine, auranofin, } \\
\text { injectable gold, penicillamine }\end{array}$ & $\begin{array}{l}3.6 \\
3.5\end{array}$ \\
\hline $\begin{array}{l}\text { Listing } \\
\text { et al }{ }^{69}\end{array}$ & $\begin{array}{l}\text { Retrospective cohort study using } \\
\text { biologic registry, Germany, } 200 \mathrm{I}-2003 \text {, } \\
n=5 I 2 \text { receiving etanercept, } \\
346 \text { infliximab, } 70 \text { anakinra }\end{array}$ & Physician diagnoses & $\begin{array}{l}\text { Nonbiologic DMARDs } \\
\text { Etanercept } \\
\text { Infliximab } \\
\text { Anakinra }\end{array}$ & $\begin{array}{l}2.3(1.3-3.9) \\
6.4(4.5-9.1) \\
6.2(4.0-9.5) \\
3.2\end{array}$ \\
\hline $\begin{array}{l}\text { Askling } \\
\text { et al }{ }^{44}\end{array}$ & $\begin{array}{l}\text { Cohort study using national biologic } \\
\text { registry in Sweden, 1999-2003, } \\
n=4167\end{array}$ & $\begin{array}{l}\text { Requiring } \\
\text { hospitalization }\end{array}$ & TNF inhibitors & $\begin{array}{l}4.7 \text { overall } 4.5 \text { Ist TNF } \\
\text { inhibitor } 7.0 \text { 2nd TNF } \\
\text { inhibitor }\end{array}$ \\
\hline $\begin{array}{l}\text { Dixon } \\
\text { et } \mathrm{al}^{45}\end{array}$ & $\begin{array}{l}\text { Prospective follow-up, UK (BSRBR), } \\
\mathrm{n}=10,755,8659 \text { with TNF inhibitor, } \\
2170 \text { with traditional DMARDs }\end{array}$ & $\begin{array}{l}\text { Requiring hospitalization; } \\
\text { IV antibiotics or death }\end{array}$ & $\begin{array}{l}\text { Nonbiologic DMARDs } \\
\text { Etanercept } \\
\text { Infliximab } \\
\text { Adalimumab } \\
\text { TNF inhibitors }\end{array}$ & $\begin{array}{l}3.9(3.2-4.7) \\
5.1(4.6-5.7) \\
6.3(5.6-7.0) \\
5.0(4.2-6.1) \\
5.6(5.2-6.0)\end{array}$ \\
\hline $\begin{array}{l}\text { Dixon } \\
\text { et } \mathrm{al}^{70}\end{array}$ & $\begin{array}{l}\text { Prospective follow-up, UK BSRBR, } \\
\mathrm{n}=7666 \text { TNF inhibitor and I } 354 \text { for } \\
\text { traditional DMARDs }\end{array}$ & $\begin{array}{l}\text { Requiring hospitalization; } \\
\text { IV antibiotics or death }\end{array}$ & $\begin{array}{l}\text { Non-biologic DMARDs } \\
\text { Etanercept } \\
\text { Infliximab } \\
\text { Adalimumab } \\
\text { TNF inhibitors }\end{array}$ & $\begin{array}{l}4.1(3.1-5.4) \\
5.1(4.5-5.9) \\
5.5(4.9-6.2) \\
5.2(4.0-6.6) \\
5.3(4.9-5.8)\end{array}$ \\
\hline $\begin{array}{l}\text { Favalli } \\
\text { et } \mathrm{al}^{71}\end{array}$ & $\begin{array}{l}\text { LORHEN registry (Italy), } 36 \text { months } \\
\text { of FU after first use of TNF } \\
\text { inhibitors, } \mathrm{n}=1064\end{array}$ & $\begin{array}{l}\text { Requiring hospitalization; } \\
\text { IV antibiotics, death, or } \\
\text { significant medical risk }\end{array}$ & $\begin{array}{l}\text { Etanercept } \\
\text { Infliximab } \\
\text { Adalimumab } \\
\text { All }\end{array}$ & $\begin{array}{l}2.6(1.0-4.1) \\
3.9(2.7-5.1) \\
3.8(2.1-5.5) \\
3.6(2.8-4.4)\end{array}$ \\
\hline $\begin{array}{l}\text { Galloway } \\
\text { et } \mathrm{al}^{72}\end{array}$ & $\begin{array}{l}\text { BSRBR UK, prospective FU, } \\
\mathrm{n}=1 \mathrm{I}, 798 \text { TNF inhibitors and } \\
3598 \text { nonbiologic DMARDs }\end{array}$ & $\begin{array}{l}\text { Requiring hospitalization; } \\
\text { IV antibiotics or death }\end{array}$ & $\begin{array}{l}\text { Nonbiologic DMARDs } \\
\text { TNF inhibitors } \\
\text { Etanercept } \\
\text { Infliximab } \\
\text { Adalimumab }\end{array}$ & $\begin{array}{l}3.2(2.8-3.6) \\
4.2(4.0-4.4) \\
3.8(3.5-4.2) \\
4.6(4.2-5.0) \\
4.3(3.9-4.7)\end{array}$ \\
\hline $\begin{array}{l}\text { Curtis } \\
\text { et } \mathrm{al}^{73}\end{array}$ & $\begin{array}{l}\text { Retrospective FU, claims data, US, } \\
\text { hospitalized infections were } \\
\text { abstracted and confirmed, incidence } \\
\text { within } 6 \text { months of index }\end{array}$ & Requiring hospitalization & $\begin{array}{l}\text { TNF inhibitors } \\
\text { MTX }\end{array}$ & $\begin{array}{l}2.9 \\
1.4\end{array}$ \\
\hline $\begin{array}{l}\text { Curtis } \\
\text { et al } 7^{74}\end{array}$ & $\begin{array}{l}\text { Retrospective cohort study } \\
\text { in claims database }\end{array}$ & Requiring hospitalization & $\begin{array}{l}\text { Biologic DMARDs } \\
\text { (previous biologic-free) } \\
\text { Biologic DMARDs } \\
\text { (biological switcher) }\end{array}$ & $\begin{array}{l}4.6 \\
7.0\end{array}$ \\
\hline $\begin{array}{l}\text { Salliot } \\
\text { et } \mathrm{al}^{75} \\
\text { den Broeder } \\
\text { et } \mathrm{al}^{76}\end{array}$ & $\begin{array}{l}\text { Retrospective review at I center, } \\
\text { 1997-2004, France, } n=709 \\
\text { Cohort study at } 6 \text { centers, } \\
2002-2004, n=146, \text { Netherlands }\end{array}$ & $\begin{array}{l}\text { Requiring hospitalization } \\
\text { or life-threatening }\end{array}$ & $\begin{array}{l}\text { TNF inhibitors } \\
\text { Anakinra }\end{array}$ & $\begin{array}{l}\text { 3.4 prior to TNF inhibitor } \\
\text { 10.4 after TNF inhibitor } \\
0.97\end{array}$ \\
\hline $\begin{array}{l}\text { Koike } \\
\text { et } \mathrm{al}^{77}\end{array}$ & $\begin{array}{l}\text { Postmarketing surveillance, Japan, } \\
\mathrm{n}=388 \mathrm{I}\end{array}$ & $\begin{array}{l}\text { Clinically important } \\
\text { events }\end{array}$ & Tocilizumab & 9.1 \\
\hline $\begin{array}{l}\text { Mariette } \\
\text { et a }{ }^{78}\end{array}$ & TNF inhibitor registries, France & $\begin{array}{l}\text { Requiring hospitalization; } \\
\text { IV antibiotics or death }\end{array}$ & TNF inhibitors & $\begin{array}{l}4.5-5.0 \text { depending } \\
\text { on registry }\end{array}$ \\
\hline $\begin{array}{l}\text { Komano } \\
\text { et } \mathrm{a}^{79}\end{array}$ & $\begin{array}{l}\text { Longitudinal RA registry, } \\
\mathrm{n}=|| \mid 44 \text {; Japan }\end{array}$ & $\begin{array}{l}\text { Infections meeting } \\
\text { definition of SAE }\end{array}$ & $\begin{array}{l}\text { Infliximab or etanercept } \\
\text { Nonbiologic DMARDs }\end{array}$ & $\begin{array}{l}6.4 \\
2.6\end{array}$ \\
\hline
\end{tabular}


Table 2 (Continued)

\begin{tabular}{|c|c|c|c|c|}
\hline Studies & Study information & Definition of SI & Drugs & Incidence per I00 PYa \\
\hline Grijalva & Multicenter cohort study, US, & Requiring hospitalization & TNF inhibitors & 8.2 \\
\hline \multirow[t]{4}{*}{ et $\mathrm{al}^{80}$} & $\mathrm{n}=10,484$ & & Nonbiologic therapy & 7.8 \\
\hline & & & Infliximab & 10.3 \\
\hline & & & Adalimumab & 8.7 \\
\hline & & & Etanercept & 6.8 \\
\hline Strangfeld & Longitudinal RA registry, & & TNF inhibitors & 2.2-4.8 depending on \\
\hline et $\mathrm{al}^{46}$ & Germany, n = 5044 & & & time since treatment start \\
\hline Bernatskyl & Nested case-control study, & Requiring hospitalization & DMARDs & 1.3 \\
\hline $2007^{81}$ & $\mathrm{n}=23,733,1980-2002$, Canada & & (including mostly nonbiologic) & \\
\hline Doran & Retrospective cohort study, & Requiring hospitalization & Corticoid and nonbiologic & 9.6 \\
\hline et $\mathrm{al}^{82}$ & $1955-1994, n=609$ & & DMARDs & \\
\hline
\end{tabular}

Note: a Values in parentheses are the $95 \%$ confidence intervals.

Abbreviations: BSRBR, British Society for Rheumatology Biologics Register; DMARDs, disease-modifying antirheumatic drugs; FU, follow-up; IV, intravenous; LORHEN, Lombardy Rheumatology Network; MTX, methotrexate; PY, person-year; RA, rheumatoid arthritis; SI, serious infection; TNF, tumor necrosis factor; UK, United Kingdom; US, United States; VA, Veterans Affairs.

incidence of SI among individual biologics or between different classes of biologic DMARDs, the relative consistency of findings among the majority of approved therapies suggests that any differences, if they exist, may be small. Our review showed that there was a lack of incidence data on OI and TB, especially from observational studies. Even for clinical trials, available data on OI and TB were scarce. The ranges of incidence for OI and TB were wide - 0.01-3.0/100 PY and 0.01-2.6/100 PY, respectively (Table 3) - reflecting the limited amount of data and high variability among studies.

Estimates of the absolute incidence reported from clinical trials and observational studies may differ, given their different designs. Study subjects included in the clinical trials are often highly selected. Trials are often of small size and with short duration, making it difficult to obtain stable estimates, especially for rare outcomes. On the other hand, observational

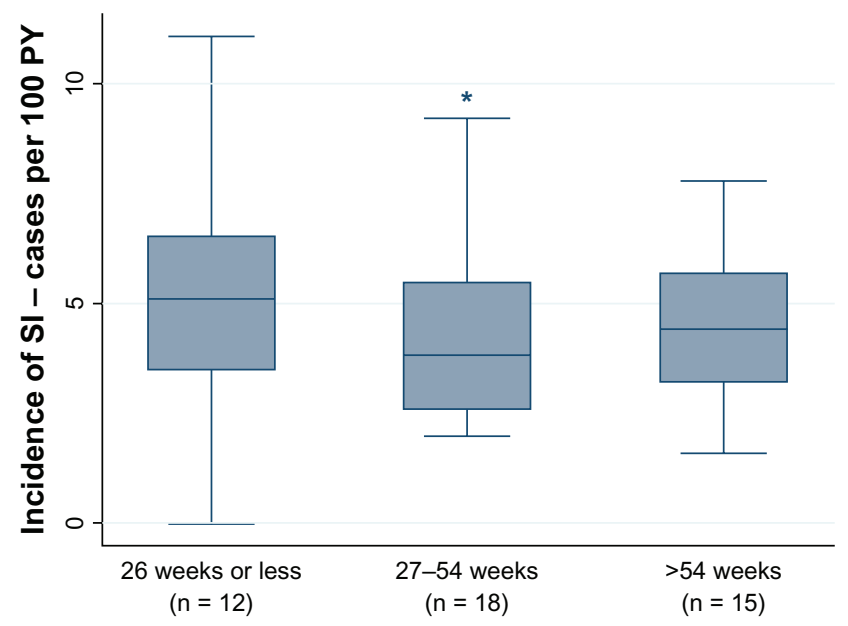

Figure 2 Incidence density of serious infections after biologic treatment by duration of follow-up - data from RCT and OLE studies only.

Abbreviations: OLE, open-label extension; PY, person-year; RCT, randomized controlled trial; SI, serious infection. studies are conducted in less selected populations, of larger size, and with longer duration. However, follow-up procedure for adverse events in observational studies is often not as rigorous as in clinical trials, potentially leading to an underestimation of certain types of adverse event. On the other hand, capture of broadly defined or unconfirmed events may lead to overestimation. In this review, the incidence of SI reported from observational studies was relatively consistent with that from clinical trials, suggesting that infections requiring hospitalization is a reasonable definition of SIs in the observational setting. This suggests that infections requiring IV antibiotics, which were life-threatening or fatal,

Table 3 Range of incidence density of Sls, Ols, and TB in RA patients receiving biologic DMARDs - data from RCT, OLE, and observational studies

\begin{tabular}{|c|c|c|c|}
\hline \multirow[t]{2}{*}{$\overline{\text { Drugs }}$} & \multicolumn{3}{|c|}{ Incidence per I00 PY (range) } \\
\hline & $\overline{S \mathbf{I}^{\mathbf{a}}}$ & OI & TB \\
\hline Rituximab & $2.0-5.2$ & - & - \\
\hline Etanercept & $2.6-11.1$ & $0.01-0.12^{\mathrm{a}}$ & $0.0 \mathrm{I}-0.1 \mathrm{I}^{\mathrm{a}}$ \\
\hline Adalimumab & $2.0-8.7$ & $0.03-1.12^{\mathrm{a}}$ & $0.08-0.56^{2}$ \\
\hline Abatacept & $1.6-4.3$ & 0.2 & 0.18 \\
\hline Infliximab & $3.9-10.3$ & $0.29-2.6^{\mathrm{a}}$ & $0.05-2.6^{\mathrm{a}}$ \\
\hline Anakinra & I.0-5.4 & 0.13 & - \\
\hline Certolizumab & $4.0-7.3$ & - & $0.7-2.5$ \\
\hline Tocilizumab & $3.1-9.1$ & $0.15-1.1$ & $0.08-0.09$ \\
\hline Golimumab & $2.5-10.0$ & - & $0.46-1.4$ \\
\hline TNF inhibitors & $2.2-10.4$ & $0.15-3.0^{\mathrm{a}}$ & - \\
\hline Biologic DMARDs & $4.6-7.0$ & - & - \\
\hline Methotrexate & $1.0-8.8$ & - & - \\
\hline $\begin{array}{l}\text { Nonbiologic DMARDs } \\
\text { and corticoid }\end{array}$ & $1.3-9.6$ & - & - \\
\hline
\end{tabular}

Note: a Data were also from observational studies.

Abbreviations: DMARDs, disease-modifying antirheumatic drugs; OI, opportunistic infection; OLE, open-label extension; PY, person-year; RA, rheumatoid arthritis; RCT, randomized clinical trial; SI, serious infection; TB, tuberculosis; TNF, tumor necrosis factor. 
or those resulting in significant medical risk, ie, the other components of the SI definition used in clinical trials, may occur relatively rarely outside the hospital setting.

In this review, we did not observe any important difference in the distribution of incidence of SI in RA patients by duration of follow-up in clinical trials or their long-term extensions. The first two categories, ie, 26 weeks or less and 26-54 weeks, were the two most common follow-up periods of RCTs; the third category, ie, more than 54 weeks, often corresponded to OLE studies. This finding is in agreement with several OLE studies that observed negligible differences in incidence of SI between the main randomized studies and the extension periods. ${ }^{15,41,42}$ However, this qualitative assessment of the distribution of SI incidence should be interpreted with caution, because we are not comparing the statistics in a controlled setting. A meta-regression of data from 18 RCTs in RA patients suggested that the odds ratios of SI are inversely correlated with duration of the trials. ${ }^{4}$ Several observational studies have also suggested that the risk of SI was highest within the first year after the initiation of a biologic therapy. ${ }^{43-46}$ The larger size of observational studies and of the meta-analysis might have helped observe the trend by time on treatment, whereas smaller individual extension studies did not. This may be due to a true higher risk of SI in the first few months of therapy, but may also be in part due to the depletion of susceptible patients. Those at high risk of SI may not be prescribed treatment, or those experiencing SI may have stopped the treatment, thus leaving a healthier cohort that remains on treatment. ${ }^{46}$

Due to the relatively rare occurrence of OI and TB in a clinical trial setting, only a few studies reported OI and TB. Even in trials that reported OI, the definition of OI was often not presented and may vary among different reports. This lack of a consistent definition may contribute to the broad variation of incidence density reported in this area. Although some studies considered TB an OI and included TB cases in the overall calculation of OI incidence, ${ }^{26,30,41,47}$ others did not. TB is relatively common compared to other OI; thus the inclusion of TB as an OI could artificially inflate the incidence of OI when compared to studies that do not include TB in this class. Therefore, a benchmark rate for OI as a composite category should be interpreted with caution. It is important that future studies consistently define and report OI and TB. The reported incidence of TB associated with biologic treatment in RA patients also varied greatly, in part due to the small size of studies, the rarity of TB, the difference in background incidence of TB in specific geographical regions, ${ }^{36}$ and the intrinsic difference in the risk for TB associated with the mechanism of action of a specific agent. Given the limited data, little is known of the temporal distribution of $\mathrm{OI}$ and TB in RA patients treated with biologic DMARDs. It is unfortunate that larger observational studies with longer follow-up have not been able to detect OI reliably, considering that $\mathrm{OI}$ is not adequately captured in routine practice. Prospective registries of RA patients may be an appropriate setting to study the risk of rare events like OI and TB in RA patients, but this will require improved methods of capturing this information validly and consistently.

For the first time, we summarize here the absolute incidence density of SI, OI, and TB associated with each of the nine biologic DMARDs currently available for treatment of RA. In clinical trials, the incidence of events was reported either as a cumulative incidence or an incidence density. Because the cumulative incidence is directly related to the duration of the follow-up - ie, the longer the follow-up is, the higher the cumulative risk of experiencing the event - it is not an optimal measure to compare the risk between studies of different lengths of follow-up. In contrast, the incidence density, which takes into account the difference in follow-up time among individuals, is likely to be a better measure of disease frequency to compare between studies. Our effort to estimate the incidence density using available data in some studies that did not present incidence density helped provide information for some molecules (infliximab, golimumab).

This analysis has several limitations. The summarized range of incidence data does not discuss specifics on study inclusion/exclusion criteria, quality of the included studies, background characteristics of the study population, or variation across geographic regions. Therefore, the range of incidence presented here may not be applicable to all populations. The reported incidence density was likewise not adjusted for doses of the molecules under study. Some previous studies have suggested a dose-dependent increase in the risk of SI. ${ }^{43}$ However, this review showed that the reported incidence densities of SI were rather consistent across studies. Most trials included patients receiving both a biologic DMARD under study and MTX, making it difficult to sort out the incidence of infections in patients receiving the molecule under study as a monotherapy. This also applied to observational studies, most of which could not obtain an incidence among those who received biologic monotherapy treatment. Thus, the incidence of infections reported in this review is not directly applicable to treatment with biologic DMARDs as monotherapy. Appropriate screening might mitigate the risk of TB reactivation in RA patients. ${ }^{33,48}$ Earlier trials may not have had their patients screened for $\mathrm{TB}$, and it was not clear what proportion of clinical trials reviewed had their patients 
screened for TB prior to enrollment. The small number of studies per molecule, the limited amount of information available for infections or TB from each study, and the heterogeneity of the study designs and populations did not allow us to perform a meta-analysis with the available data.

In conclusion, this review discussed the absolute incidence density of SI, OI, and TB associated with biologic treatment in RA patients. The SI data may be used to evaluate the public health risk and benefit of each biologic treatment, as well as serving as a point of reference for future studies. The limited data on OI and TB and the lack of a consistent definition of OI invite caution for a benchmark rate for OI as a composite category.

\section{Acknowledgments}

This work was supported by MedImmune, LLC. We thank Professor Iain McInnes of the University of Glasgow for his review of and comments on the manuscript. We thank Ms Carrie Lancos of MedImmune, LLC, for her help with editing and formatting the manuscript.

\section{Disclosure}

TNT and HC are employees of MedImmune, LLC. FM is a former employee of MedImmune, and is a current employee of Eli Lilly and Company.

\section{References}

1. Furst DE, Keystone EC, Braun J, et al. Updated consensus statement on biological agents for the treatment of rheumatic diseases, 2010. Ann Rheum Dis. 2011;70 Suppl 1:i2-i36.

2. Bongartz T, Sutton AJ, Sweeting MJ, Buchan I, Matteson EL, Montori V. Anti-TNF antibody therapy in rheumatoid arthritis and the risk of serious infections and malignancies: systematic review and meta-analysis of rare harmful effects in randomized controlled trials. JAMA. 2006;295(19): 2275-2285.

3. Ellerin T, Rubin RH, Weinblatt ME. Infections and anti-tumor necrosis factor alpha therapy. Arthritis Rheum. 2003;48(11):3013-3022.

4. Leombruno JP, Einarson TR, Keystone EC. The safety of anti-tumour necrosis factor treatments in rheumatoid arthritis: meta and exposureadjusted pooled analyses of serious adverse events. Ann Rheum Dis. 2009;68(7):1136-1145.

5. Singh JA, Wells GA, Christensen R, et al. Adverse effects of biologics: a network meta-analysis and Cochrane overview. Cochrane Database Syst Rev. 2011;2:CD008794.

6. Keystone EC. Does anti-tumor necrosis factor-alpha therapy affect risk of serious infection and cancer in patients with rheumatoid arthritis? A review of longterm data. J Rheumatol. 2011;38(8):1552-1562.

7. Tam LS, Leung CC, Ying SK, et al. Risk of tuberculosis in patients with rheumatoid arthritis in Hong Kong - the role of TNF blockers in an area of high tuberculosis burden. Clin Exp Rheumatol. 2010;28(5):679-685.

8. Harris J, Keane J. How tumour necrosis factor blockers interfere with tuberculosis immunity. Clin Exp Immunol. 2010;161(1):1-9.

9. Centers for Disease Control and Prevention (CDC). 1993 Revised classification system for HIV infection and expanded surveillance case definition for AIDS among adolescents and adults, United States. 1993. Available from: http://www.cdc.gov/mmwr/preview/mmwrhtml/00018871.htm. Accessed February 27, 2012.
10. Delabaye I, De Keyser F; REMITRACT study group. 74-Week follow-up of safety of infliximab in patients with refractory rheumatoid arthritis. Arthritis Res Ther. 2010;12(3):R121.

11. Maini R, St Clair EW, Breedveld F, et al. Infliximab (chimeric antitumour necrosis factor alpha monoclonal antibody) versus placebo in rheumatoid arthritis patients receiving concomitant methotrexate: a randomised phase III trial. ATTRACT study group. Lancet. 1999; 354(9194):1932-1939.

12. St Clair EW, van der Heijde DM, Smolen JS, et al. Combination of infliximab and methotrexate therapy for early rheumatoid arthritis: a randomized, controlled trial. Arthritis Rheum. 2004;50(11):3432-3443.

13. Westhovens R, Yocum D, Han J, et al. The safety of infliximab, combined with background treatments, among patients with rheumatoid arthritis and various comorbidities: a large, randomized, placebocontrolled trial. Arthritis Rheum. 2006;54(4):1075-1086.

14. Smolen J, Landewe RB, Mease P, et al. Efficacy and safety of certolizumab pegol plus methotrexate in active rheumatoid arthritis: the RAPID 2 study. A randomised controlled trial. Ann Rheum Dis. 2009; 68(6):797-804.

15. Kremer J, Ritchlin C, Mendelsohn A, et al. Golimumab, a new human anti-tumor necrosis factor alpha antibody, administered intravenously in patients with active rheumatoid arthritis: forty-eight-week efficacy and safety results of a phase III randomized, double-blind, placebocontrolled study. Arthritis Rheum. 2010;62(4):917-928.

16. Emery P, Fleischmann RM, Moreland LW, et al. Golimumab, a human anti-tumor necrosis factor alpha monoclonal antibody, injected subcutaneously every four weeks in methotrexate-naive patients with active rheumatoid arthritis: twenty-four-week results of a phase III, multicenter, randomized, double-blind, placebo-controlled study of golimumab before methotrexate as first-line therapy for early-onset rheumatoid arthritis. Arthritis Rheum. 2009;60(8):2272-2283.

17. Kay J, Matteson EL, Dasgupta B, et al. Golimumab in patients with active rheumatoid arthritis despite treatment with methotrexate: a randomized, double-blind, placebo-controlled, dose-ranging study. Arthritis Rheum. 2008;58(4):964-975.

18. Genovese MC, Covarrubias A, Leon G, et al. Subcutaneous abatacept versus intravenous abatacept: a phase IIIb noninferiority study in patients with an inadequate response to methotrexate. Arthritis Rheum. 2011;63(10):2854-2864.

19. Westhovens R, Robles M, Ximenes AC, et al. Clinical efficacy and safety of abatacept in methotrexate-naive patients with early rheumatoid arthritis and poor prognostic factors. Ann Rheum Dis. 2009;68(12): 1870-1877.

20. Fleischmann RM, Schechtman J, Bennett R, et al. Anakinra, a recombinant human interleukin-1 receptor antagonist (r-metHuIL-1ra), in patients with rheumatoid arthritis: a large, international, multicenter, placebo-controlled trial. Arthritis Rheum. 2003;48(4):927-934.

21. Schiff M, Keiserman M, Codding C, et al. Efficacy and safety of abatacept or infliximab vs placebo in ATTEST: a phase III, multi-centre, randomised, double-blind, placebo-controlled study in patients with rheumatoid arthritis and an inadequate response to methotrexate. Ann Rheum Dis. 2008;67(8):1096-1103.

22. Weinblatt ME, Bathon JM, Kremer JM, et al. Safety and efficacy of etanercept beyond 10 years of therapy in North American patients with early and longstanding rheumatoid arthritis. Arthritis Care Res (Hoboken). 2011;63(3):373-382.

23. Keystone EC, Kavanaugh AF, Sharp JT, et al. Radiographic, clinical, and functional outcomes of treatment with adalimumab (a human anti-tumor necrosis factor monoclonal antibody) in patients with active rheumatoid arthritis receiving concomitant methotrexate therapy: a randomized, placebo-controlled, 52-week trial. Arthritis Rheum. 2004;50(5):1400-1411.

24. Burmester GR, Mariette X, Montecucco C, et al. Adalimumab alone and in combination with disease-modifying antirheumatic drugs for the treatment of rheumatoid arthritis in clinical practice: the research in active rheumatoid arthritis (ReAct) trial. Ann Rheum Dis. 2007;66(6): $732-739$. 
25. Kremer JM, Russell AS, Emery P, et al. Long-term safety, efficacy and inhibition of radiographic progression with abatacept treatment in patients with rheumatoid arthritis and an inadequate response to methotrexate: 3-year results from the AIM trial. Ann Rheum Dis. 2011;70(10): 1826-1830.

26. Fleischmann RM, Tesser J, Schiff MH, et al. Safety of extended treatment with anakinra in patients with rheumatoid arthritis. Ann Rheum Dis. 2006;65(8):1006-1012.

27. Schiff MH, Kremer JM, Jahreis A, Vernon E, Isaacs JD, van Vollenhoven RF. Integrated safety in tocilizumab clinical trials. Arthritis Res Ther. 2011;13(5):R141.

28. Nishimoto N, Ito K, Takagi N. Safety and efficacy profiles of tocilizumab monotherapy in Japanese patients with rheumatoid arthritis: meta-analysis of six initial trials and five long-term extensions. Mod Rheumatol. 2010;20(3):222-232.

29. Cohen S, Hurd E, Cush J, et al. Treatment of rheumatoid arthritis with anakinra, a recombinant human interleukin-1 receptor antagonist, in combination with methotrexate: results of a twenty-four-week, multicenter, randomized, double-blind, placebo-controlled trial. Arthritis Rheum. 2002;46(3):614-624.

30. Greenberg JD, Reed G, Kremer JM, et al. Association of methotrexate and tumour necrosis factor antagonists with risk of infectious outcomes including opportunistic infections in the CORRONA registry. Ann Rheum Dis. 2010;69(2):380-386.

31. Salmon-Ceron D, Tubach F, Lortholary O, et al. Drug-specific risk of non-tuberculosis opportunistic infections in patients receiving anti-TNF therapy reported to the 3-year prospective French RATIO registry. Ann Rheum Dis. 2011;70(4):616-623.

32. Wallis RS, Broder M, Wong J, Beenhouwer D. Granulomatous infections due to tumor necrosis factor blockade: correction. Clin Infect Dis. 2004;39(8):1254-1255.

33. Gomez-Reino JJ, Carmona L, Angel DM. Risk of tuberculosis in patients treated with tumor necrosis factor antagonists due to incomplete prevention of reactivation of latent infection. Arthritis Rheum 2007;57(5):756-761

34. Tubach F, Salmon D, Ravaud P, et al. Risk of tuberculosis is higher with anti-tumor necrosis factor monoclonal antibody therapy than with soluble tumor necrosis factor receptor therapy: the three-year prospective French Research Axed on Tolerance of Biotherapies registry. Arthritis Rheum. 2009;60(7):1884-1894.

35. Dixon WG, Hyrich KL, Watson KD, et al. Drug-specific risk of tuberculosis in patients with rheumatoid arthritis treated with anti-TNF therapy: results from the British Society for Rheumatology Biologics Register (BSRBR). Ann Rheum Dis. 2010;69(3):522-528.

36. Seong SS, Choi CB, Woo JH, et al. Incidence of tuberculosis in Korean patients with rheumatoid arthritis (RA): effects of RA itself and of tumor necrosis factor blockers. J Rheumatol. 2007;34(4): 706-711.

37. Askling J, Fored CM, Brandt L, et al. Risk and case characteristics of tuberculosis in rheumatoid arthritis associated with tumor necrosis factor antagonists in Sweden. Arthritis Rheum. 2005;52(7): 1986-1992.

38. Wolfe F, Michaud K, Anderson J, Urbansky K. Tuberculosis infection in patients with rheumatoid arthritis and the effect of infliximab therapy. Arthritis Rheum. 2004;50(2):372-379.

39. Keane J, Gershon S, Wise RP, et al. Tuberculosis associated with infliximab, a tumor necrosis factor alpha-neutralizing agent. $N$ Engl J Med. 2001;345(15):1098-1104.

40. Furst DE. The risk of infections with biologic therapies for rheumatoid arthritis. Semin Arthritis Rheum. 2010;39(5):327-346.

41. Schiff M, Keiserman M, Codding C, et al. Clinical response and tolerability to abatacept in patients with rheumatoid arthritis previously treated with infliximab or abatacept: open-label extension of the ATTEST study. Ann Rheum Dis. 2011;70(11):2003-2007.

42. Simon TA, Askling J, Lacaille D, et al. Infections requiring hospitalization in the abatacept clinical development program: an epidemiological assessment. Arthritis Res Ther. 2010;12(2):R67.
43. Lane MA, McDonald JR, Zeringue AL, et al. TNF-alpha antagonist use and risk of hospitalization for infection in a national cohort of veterans with rheumatoid arthritis. Medicine (Baltimore). 2011;90(2): $139-145$.

44. Askling J, Fored CM, Brandt L, et al. Time-dependent increase in risk of hospitalisation with infection among Swedish RA patients treated with TNF antagonists. Ann Rheum Dis. 2007;66(10):1339-1344.

45. Dixon WG, Symmons DP, Lunt M, Watson KD, Hyrich KL, Silman AJ. Serious infection following anti-tumor necrosis factor alpha therapy in patients with rheumatoid arthritis: lessons from interpreting data from observational studies. Arthritis Rheum. 2007;56(9): 2896-2904

46. Strangfeld A, Eveslage M, Schneider M, et al. Treatment benefit or survival of the fittest: what drives the time-dependent decrease in serious infection rates under TNF inhibition and what does this imply for the individual patient? Ann Rheum Dis. 2011;70(11):1914-1920.

47. Gottlieb AB, Gordon K, Giannini EH, et al. Clinical trial safety and mortality analyses in patients receiving etanercept across approved indications. J Drugs Dermatol. 2011;10(3):289-300.

48. Schiff MH, Burmester GR, Kent JD, et al. Safety analyses of adalimumab (HUMIRA) in global clinical trials and US postmarketing surveillance of patients with rheumatoid arthritis. Ann Rheum Dis. 2006;65(7):889-894.

49. Klareskog L, Gaubitz M, Rodriguez-Valverde V, Malaise M, Dougados M, Wajdula J. Assessment of long-term safety and efficacy of etanercept in a 5-year extension study in patients with rheumatoid arthritis. Clin Exp Rheumatol. 2011;29(2):238-247.

50. Weisman MH, Paulus HE, Burch FX, et al. A placebo-controlled, randomized, double-blinded study evaluating the safety of etanercept in patients with rheumatoid arthritis and concomitant comorbid diseases. Rheumatology (Oxford). 2007;46(7):1122-1125.

51. Moreland LW, Weinblatt ME, Keystone EC, et al. Etanercept treatment in adults with established rheumatoid arthritis: 7 years of clinical experience. J Rheumatol. 2006;33(5):854-861.

52. Weinblatt ME, Keystone EC, Furst DE, Kavanaugh AF, Chartash EK, Segurado OG. Long term efficacy and safety of adalimumab plus methotrexate in patients with rheumatoid arthritis: ARMADA 4 year extended study. Ann Rheum Dis. 2006;65(6):753-759.

53. Keystone EC, Kavanaugh A, Weinblatt ME, Patra K, Pangan AL. Clinical consequences of delayed addition of adalimumab to methotrexate therapy over 5 years in patients with rheumatoid arthritis. J Rheumatol. 2011;38(5):855-862.

54. Burmester GR, Mease P, Dijkmans BA, et al. Adalimumab safety and mortality rates from global clinical trials of six immune-mediated inflammatory diseases. Ann Rheum Dis. 2009;68(12):1863-1869.

55. Fleischmann R, Vencovsky J, van Vollenhoven RF, et al. Efficacy and safety of certolizumab pegol monotherapy every 4 weeks in patients with rheumatoid arthritis failing previous disease-modifying antirheumatic therapy: the FAST4WARD study. Ann Rheum Dis. 2009;68(6): 805-811.

56. Keystone E, Heijde D, Mason D Jr, et al. Certolizumab pegol plus methotrexate is significantly more effective than placebo plus methotrexate in active rheumatoid arthritis: findings of a fifty-two-week, phase III, multicenter, randomized, double-blind, placebo-controlled, parallel-group study. Arthritis Rheum. 2008;58(11):3319-3329.

57. Keystone E, Genovese MC, Klareskog L, et al. Golimumab in patients with active rheumatoid arthritis despite methotrexate therapy: 52-week results of the GO-FORWARD study. Ann Rheum Dis. 2010;69(6): 1129-1135.

58. Cohen SB, Emery P, Greenwald MW, et al. Rituximab for rheumatoid arthritis refractory to anti-tumor necrosis factor therapy: results of a multicenter, randomized, double-blind, placebo-controlled, phase III trial evaluating primary efficacy and safety at twenty-four weeks. Arthritis Rheum. 2006;54(9):2793-2806.

59. van Vollenhoven RF, Emery P, Bingham CO 3rd, et al. Longterm safety of patients receiving rituximab in rheumatoid arthritis clinical trials. J Rheumatol. 2010;37(3):558-567. 
60. Keystone E, Fleischmann R, Emery P, et al. Safety and efficacy of additional courses of rituximab in patients with active rheumatoid arthritis: nn open-label extension analysis. Arthritis Rheum. 2007;56(12): 3896-3908.

61. Emery P, Deodhar A, Rigby WF, et al. Efficacy and safety of different doses and retreatment of rituximab: a randomised, placebo-controlled trial in patients who are biological naive with active rheumatoid arthritis and an inadequate response to methotrexate (study evaluating rituximab's efficacy in MTX inadequate responders [SERENE]). Ann Rheum Dis. 2010;69(9):1629-1635.

62. Kremer JM, Genant HK, Moreland LW, et al. Results of a two-year followup study of patients with rheumatoid arthritis who received a combination of abatacept and methotrexate. Arthritis Rheum. 2008;58(4): 953-963.

63. Yazici Y, Curtis JR, Ince A, et al. Efficacy of tocilizumab in patients with moderate to severe active rheumatoid arthritis and a previous inadequate response to disease-modifying antirheumatic drugs: the ROSE study. Ann Rheum Dis. 2012;71(2):198-205.

64. Kremer JM, Blanco R, Brzosko M, et al. Tocilizumab inhibits structural joint damage in rheumatoid arthritis patients with inadequate responses to methotrexate: results from the double-blind treatment phase of a randomized placebo-controlled trial of tocilizumab safety and prevention of structural joint damage at one year. Arthritis Rheum. 2011;63(3): 609-621.

65. Nishimoto N, Miyasaka N, Yamamoto K, Kawai S, Takeuchi T, Azuma J. Long-term safety and efficacy of tocilizumab, an anti-IL-6 receptor monoclonal antibody, in monotherapy, in patients with rheumatoid arthritis (the STREAM study): evidence of safety and efficacy in a 5-year extension study. Ann Rheum Dis. 2009;68(10):1580-1584.

66. Smolen JS, Beaulieu A, Rubbert-Roth A, et al. Effect of interleukin-6 receptor inhibition with tocilizumab in patients with rheumatoid arthritis (OPTION study): a double-blind, placebo-controlled, randomised trial. Lancet. 2008;371(9617):987-997.

67. Rigby W, Tony HP, Oelke K, et al. Safety and efficacy of ocrelizumab in patients with rheumatoid arthritis and an inadequate response to methotrexate: results of a forty-eight-week randomized, double-blind, placebo-controlled, parallel-group phase III trial. Arthritis Rheum. 2012; 64(2):350-359.

68. Lacaille D, Guh DP, Abrahamowicz M, Anis AH, Esdaile JM. Use of nonbiologic disease-modifying antirheumatic drugs and risk of infection in patients with rheumatoid arthritis. Arthritis Rheum. 2008;59(8): 1074-1081.

69. Listing J, Strangfeld A, Kary S, et al. Infections in patients with rheumatoid arthritis treated with biologic agents. Arthritis Rheum. 2005;52(11): 3403-3412.

70. Dixon WG, Watson K, Lunt M, Hyrich KL, Silman AJ, Symmons DP. Rates of serious infection, including site-specific and bacterial intracellular infection, in rheumatoid arthritis patients receiving anti-tumor necrosis factor therapy: results from the British Society for Rheumatology Biologics Register. Arthritis Rheum. 2006;54(8):2368-2376.
71. Favalli EG, Desiati F, Atzeni F, et al. Serious infections during antiTNFalpha treatment in rheumatoid arthritis patients. Autoimmun Rev. 2009;8(3):266-273.

72. Galloway JB, Hyrich KL, Mercer LK, et al. Anti-TNF therapy is associated with an increased risk of serious infections in patients with rheumatoid arthritis especially in the first 6 months of treatment: updated results from the British Society for Rheumatology Biologics Register with special emphasis on risks in the elderly. Rheumatology (Oxford). 2011;50(1):124-131.

73. Curtis JR, Martin C, Saag KG, et al. Confirmation of administrative claims-identified opportunistic infections and other serious potential adverse events associated with tumor necrosis factor alpha antagonists and disease-modifying antirheumatic drugs. Arthritis Rheum. 2007;57(2):343-346.

74. Curtis JR, Xie F, Chen L, et al. The comparative risk of serious infections among rheumatoid arthritis patients starting or switching biological agents. Ann Rheum Dis. 2011;70(8):1401-1406.

75. Salliot C, Gossec L, Ruyssen-Witrand A, et al. Infections during tumour necrosis factor-alpha blocker therapy for rheumatic diseases in daily practice: a systematic retrospective study of 709 patients. Rheumatology (Oxford). 2007;46(2):327-334.

76. den Broeder AA, de Jong E, Franssen MJ, Jeurissen ME, Flendrie M, van den Hoogen FH. Observational study on efficacy, safety, and drug survival of anakinra in rheumatoid arthritis patients in clinical practice. Ann Rheum Dis. 2006;65(6):760-762.

77. Koike T, Harigai M, Inokuma S, et al. Postmarketing surveillance of tocilizumab for rheumatoid arthritis in Japan: interim analysis of 3881 patients. Ann Rheum Dis. 2011;70(12):2148-2151.

78. Mariette X, Gottenberg JE, Ravaud P, Combe B. Registries in rheumatoid arthritis and autoimmune diseases: data from the French registries. Rheumatology (Oxford). 2011;50(1):222-229.

79. Komano Y, Tanaka M, Nanki T, et al. Incidence and risk factors for serious infection in patients with rheumatoid arthritis treated with tumor necrosis factor inhibitors: a report from the registry of Japanese rheumatoid arthritis patients for longterm safety. J Rheumatol. 2011;38(7): 1258-1264.

80. Grijalva CG, Chen L, Delzell E, et al. Initiation of tumor necrosis factoralpha antagonists and the risk of hospitalization for infection in patients with autoimmune diseases. JAMA. 2011;306(21):2331-2339.

81. Bernatsky S, Hudson M, Suissa S. Anti-rheumatic drug use and risk of serious infections in rheumatoid arthritis. Rheumatology (Oxford). 2007;46(7):1157-1160.

82. Doran MF, Crowson CS, Pond GR, O'Fallon WM, Gabriel SE. Frequency of infection in patients with rheumatoid arthritis compared with controls: a population-based study. Arthritis Rheum. 2002;46(9): 2287-2293.
Open Access Rheumatology Research and Reviews

\section{Publish your work in this journal}

Open Access Rheumatology Research and Reviews is an international, peer-reviewed, open access journal, publishing all aspects of clinical and experimental rheumatology in the clinic and laboratory including the following topics: Pathology, pathophysiology of rheumatological diseases; Investigation, treatment and management of rheumatological

\section{Dovepress}

diseases; Clinical trials and novel pharmacological approaches for the treatment of rheumatological disorders. The manuscript management system is completely online and includes a very quick and fair peerreview system, which is all easy to use. Visit http://www.dovepress.com/ testimonials.php to read real quotes from published authors. 